\title{
SPORTUOJANČIŲ STUDENTŲ (VYRŲ IR MOTERŲ) TAIKOMI STRESO IৃVEIKIMO BŪDAI
}

\author{
Vida Ivaškiene் ${ }^{1}$, Liudmila Kšanauskiené ${ }^{1}$, Jurgita Čepelioniené $\dot{1}^{1,2}$, \\ Jolanta Bogužiené ${ }^{3}$, Dainius Daukšas ${ }^{4}$ \\ Lietuvos kūno kultūros akademija, Kaunas ${ }^{1}$, Mykolo Romerio universitetas, Vilnius ${ }^{2}$, Všl „, Amžiaus \\ žiedas “ Alzheimerio slaugos namai, Kaunas ${ }^{3}$, Kauno sporto klubas „,Dainralfas", Kaunas ${ }^{4}$, Lietuva
}

Vida Ivaškienė. Docentė socialinių mokslų daktarè. Lietuvos kūno kultūros akademijos Sporto pedagogikos ir psichologijos katedros docentė. Mokslinių tyrimų kryptis — ìvairaus amžiaus žmonių fizinis pajègumas, fizinis aktyvumas ir streso įveikimo būdai.

\section{SANTRAUKA}

Tyrimo tikslas — nustatyti sportuojančiu studentu (vyru ir moteru) taikomus streso ̨̇veikimo büdus.

Metodai: literatūros šaltiniu analizè, anketinè apklausa, matematinè statistika.

Anketoje buvo pateikti 34 streso ¿̨veikimo būdai, prie kuriu respondentai turèjo pažyméti viena iš keturiu galimu atsakymo variantu, nurodydami kaip dažnai jì renkasi: $A$ - niekada, B — kartais, $C$ - dažnai, $D$ - visada.

Anonimine anketine apklausa buvo vykdoma 2007 metu lapkričio mènesi Kauno sveikatingumo ir sporto klubuose po treniruočiu. Joje dalyvavo 125 studentai (66 vyrai ir 59 moterys) nuo 18 iki 25 metu amžiaus ( $\bar{x}=22,6 \pm 2,5$ m.), lankantys treniruotes 2-3 kartus per savaitę. Pagal sportini staža respondentai buvo suskirstyti i dvi grupes: sportuojantys iki vieneriu metı ir sportuojantys daugiau kaip metus. Anketos pildymo trukmé - 10-12 minučiu.

Statistine tyrimo duomenu analizé atlikta naudojant SPSS 13.0 statistiniu duomenu apdorojimo paketa. Skirtingu grupiu rezultatu palyginimo patikimumui nustatyti buvo taikomas $\chi^{2}$ (chi kvadrato) kriterijus.

Nustatyta, kad sportuojantys studentai (vyrai ir moterys) stresui ìveikti dažniausiai taiko bendravima su šeimos nariais, juoka. Sportuojančios studentès dažniau negu sportuojantys studentai vyrai $(p<0,05)$ stresui ỉveikti taiko šokius, joga, savimasažq, kvapu terapija, pasivaikščiojima gamtoje, bendravima su šeimos nariais, su gyvūnais, augalu auginima, knygu skaityma, meldimasi, juoko terapija, požiūrio ì konfliktinę situacija keitima.

Ilgiau nei vienerius metus sportuojantys studentai, palyginti su sportuojančiais iki metu, kaip streso iveikimo büda dažniau ( $p<0,05)$ taiko mankšta, aerobinius pratimus, aktyvius ir pasyvius tempimo pratimus, autogeninę treniruotę, meditacija. Ilgiau sportuojantys vyrai dažniau taiko ritmiškq ir lèta kvèpavima, ilgiau sportuojančios moterys specialius kvépavimo pratimus.

Raktažodžiai: sportas, stresas, streso ìveikimo būdai.

\section{IVADAS}

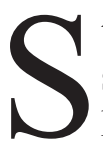
tresas yra natūralus gyvenimo reiškinys, skatinantis veiklumą, išradingumą, netgi kūrybiškumą ir tobulëjimą. Tačiau per stiprus, dažnai pasikartojantis arba užsitęsęs (lètinis) stresas gali sukelti iqvairias ligas (Selye, 1976;
O’Hanlon, 1999; Henry, 2005; Ivaškienè, Čepelionienè, 2005).

Stresą valdyti galima sureguliuojant savo mintis, taikant fizinius pratimus ar kitą mėgstamą veiklą relaksacijos tikslais (Weigant, 1998; 
Lindop, 1999; O’Hanlon, 1999; Grakauskas, Valickas, 2006). Galima taikyti įvairius streso įveikimo būdus, tokius kaip autogeninè treniruotè (O’Hanlon, 1999; Hertzer, 2003), psichofizinè treniruote (O’Hanlon, 1999; Dineika, 2001), miegas, kvėpavimo pratimai (Полтавцев, 1991; Ротх, 1994; Dineika, 2001; Henry, 2005; Palujanskienè, Pikūnas, 2005), vandens procedūros, kvapu terapija, muzikos terapija (Gray, 2001; Henry, 2005), bendravimas su artimaisiais, bendravimas su gyvūnais (Ratcliffe, 2006). Net ir juokas sukelia atsipalaidavimo jausmą, stiprina imuninę sistemą, daro žmogų laimingą, padeda jam užmiršti rūpesčius (Henry, 2005).

Fizinis aktyvumas yra viena iš veiksmingiausių streso įveikimo formų. Žmonès, kurie nuolat mankštinasi, lengviau ịveikia stresą sukeliančius veiksnius, labiau pasitiki savimi, yra mažiau prislègti negu tie, kurie nesimankština (Martinsen et al., 1989; Forge, 1993; Martinsen, 1994; Raglin, 1995; Paluska, Schwenk, 2000; Ivaškienè, 2003; Carr, 2004; Ivaškienè, Čepelionienė, 2005; Masiulis, 2006; Treben, 2006).

Žmones veikia ne tiek patys stresoriai, kiek požiūris i juos. Visgi jei negalima pakeisti situacijos, reikia keisti požiūri i ją, pamatyti nors ir mažiausias vieno ar kito įvykio teigiamybes (Weigand, 1998; Car, 2004).

Norèdami padèti susidoroti su stresu turime žinoti, kuriuos streso įveikimo būdus žmonès taiko, kurių visiškai nepropaguoja. Tačiau streso ivveikimo būdų taikymas yra menkai tyrinètas, ypač tarp sportuojančių studentų.

Tyrimo objektas — sportuojančių studentų (vyrų ir moterų) taikomi streso įveikimo būdai.

Tyrimo tikslas - nustatyti sportuojančių studentų (vyrų ir moterų) taikomus streso įveikimo būdus.

\section{Uždaviniai:}

1. Nustatyti ir palyginti sportuojančių studentu (vyru ir moterų) taikomus streso įveikimo būdus.

2. Nustatyti ir palyginti skirtingą sportini stažą turinčių respondentu taikomus streso ịveikimo būdus.

Hipotezė. Didesni sportinį stažą turintys respondentai taiko daugiau streso įveikimo būdų, moterys - daugiau nei vyrai.

\section{TYRIMO METODIKA IR ORGANIZAVIMAS}

Taikyti šie tyrimo metodai: literatūros šaltinių analizè, anketinè apklausa, matematinè statistika.

Anketa streso mažinimo būdų taikymui nustatyti parengta analizuojant literatūra, skirtą kovai su stresu. Vidinis anketos suderinamumas tinkamas (Kronbacho alfa kriterijus lygus 0,86). Anketoje buvo pateikti 34 streso mažinimo būdai, prie kurių respondentai turèjo pažymèti vieną iš keturių galimų atsakymo variantų, nurodydami kaip dažnai ji renkasi: A - niekada, B - kartais, C - dažnai, $\mathrm{D}$ - visada.

Anoniminè anketinè apklausa atlikta 2007 metų lapkričio mènesi Kauno miesto sveikatingumo ir sporto klubuose po treniruočių. Anketos pildymo trukmè $-10-12$ minučių. Buvo apklausti 125 sportuojantys studentai (66 vyrai ir 59 moterys) nuo 18 iki 25 metų amžiaus ( $\overline{\mathrm{x}}=22,6 \pm 2,5 \mathrm{~m}$.). Respondentai suskirstyti pagal du kriterijus - sportavimo stažą ir lytị. Respondentų skirstinys pagal lytị ir sportinị stažą pateiktas 1 lentelèje.

Matematinè statistika. Statistinè tyrimo duomenu analizè atlikta naudojant SPSS 13.0 statistinių duomenų apdorojimo paketą. Skirtingu grupių rezultatų palyginimo patikimumui nustatyti buvo taikomas $\chi^{2}$ (chi kvadrato) kriterijus. Skirtumas laikytas statistiškai reikšmingu, kai $\mathrm{p}<0,05$.

\section{REZULTATAI}

Sportuojančios studentès stresui iveikti taiko šokius, jogą, savimasažą, kvapu terapiją, pasivaikščiojimą gamtoje, bendravimą su gyvūnais, su šeimos nariais, augalų auginimą, knygų skaitymą, meldimąsi, požiūrio ị situaciją keitimą, juoką taiko dažniau nei sportuojantys studentai vyrai $(\mathrm{p}<0,05)(2$ lent.).

Tarp streso įveikimo būdų populiariausias yra bendravimas su šeimos nariais: visada ji taiko $18,2 \%$ vyrų ir $37,3 \%$ moteru, dažnai - atitinkamai 48,5 ir 50,8\% respondentu. Antras yra juokas: visada ji taiko $12,1 \%$ vyrų ir $13,6 \%$ moterų, dažnai atitinkamai 62,1 ir 55,9\% respondentų. Bendravima

\begin{tabular}{|l|c|c|c|}
\hline \multicolumn{1}{|c|}{ Sportavimo stažas } & Vyrai & Moterys & \multicolumn{1}{c|}{$\begin{array}{c}\text { Iš viso lentelè. Respondentų skirs- } \\
\text { tinys pagal sportavimo stažą } \\
\text { ir lyti }\end{array}$} \\
\hline Iki metų & 27 & 29 & 56 \\
\hline Daugiau kaip metus & 39 & 30 & 69 \\
\hline Iš viso & 66 & 59 & 125 \\
\hline
\end{tabular}


2 lentelè. Skirtingos lyties respondentų taikomų streso įveikimo būdų skirstinys (\%)

\begin{tabular}{|c|c|c|c|c|c|c|c|c|c|c|c|}
\hline \multirow{3}{*}{$\begin{array}{l}\text { Eil. } \\
\text { Nr. }\end{array}$} & \multirow{3}{*}{ Būdas } & \multicolumn{8}{|c|}{ Taikymo dažnumas } & \multirow{3}{*}{$\begin{array}{l}\chi^{2} \text { tarp } \\
\text { vyrų ir } \\
\text { moterų }\end{array}$} & \multirow{3}{*}{$\mathbf{p}$} \\
\hline & & \multicolumn{2}{|c|}{ Niekada } & \multicolumn{2}{|c|}{ Kartais } & \multicolumn{2}{|c|}{ Dažnai } & \multicolumn{2}{|c|}{ Visada } & & \\
\hline & & Vyrai & Moterys & Vyrai & Moterys & Vyrai & Moterys & Vyrai & Moterys & & \\
\hline 1. & Šokiai & 36,4 & 11,9 & 48,5 & 64,4 & 9,1 & 18,6 & 6,1 & 5,1 & 11,09 & $<0,05$ \\
\hline 2. & Joga & 89,4 & 69,5 & 10,6 & 25,4 & 0 & 5,1 & 0 & 0 & 8,78 & $<0,05$ \\
\hline 3. & Savimasažas & 60,6 & 32,2 & 39,4 & 57,6 & 0 & 8,5 & 0 & 1,7 & 14,19 & $<0,05$ \\
\hline 4. & Kvapų terapija & 70,3 & 27,1 & 28,1 & 49,2 & 0 & 22,0 & 1,6 & 1,7 & 29,21 & $<0,05$ \\
\hline 5. & Pasivaikščiojimai gamtoje & 6,1 & 3,4 & 65,2 & 37,3 & 27,3 & 45,8 & 1,5 & 13,6 & 14,35 & $<0,05$ \\
\hline 6. & Bendravimas su gyvūnais & 42,4 & 20,7 & 43,9 & 39,7 & 10,6 & 22,4 & 3,0 & 17,2 & 13,77 & $<0,05$ \\
\hline 7. & Augalų auginimas & 70,8 & 27,1 & 24,6 & 40,7 & 4,6 & 20,3 & 0 & 11,9 & 28,29 & $<0,05$ \\
\hline 8. & Bendravimas su šeimos nariais & 3,0 & 1,7 & 30,3 & 10,2 & 48,5 & 50,8 & 18,2 & 37,3 & 10,52 & $<0,05$ \\
\hline 9. & Knygų skaitymas & 42,4 & 8,5 & 47,0 & 45,8 & 10,6 & 33,9 & 0 & 11,9 & 29,27 & $<0,05$ \\
\hline 10. & Meldimasis & 57,6 & 33,9 & 36,4 & 42,4 & 4,5 & 13,6 & 1,5 & 10,2 & 11,09 & $<0,05$ \\
\hline 11. & Požiūrio į situaciją keitimas & 15,2 & 5,1 & 68,2 & 52,5 & 13,6 & 39,0 & 3,0 & 3,4 & 12,12 & $<0,05$ \\
\hline 12. & Juokas & 9,1 & 0 & 16,7 & 30,5 & 62,1 & 55,9 & 12,1 & 13,6 & 8,19 & $<0,05$ \\
\hline
\end{tabular}

3 lentelè. Skirtingo sportavimo stažo respondentų taikomų streso įveikimo būdų skirstinys (\%)

\begin{tabular}{|c|c|c|c|c|c|c|c|c|c|c|c|c|}
\hline \multirow{3}{*}{$\begin{array}{l}\text { Eil. } \\
\text { Nr. }\end{array}$} & \multirow[b]{3}{*}{ Būdas } & \multirow{3}{*}{ Lytis } & \multicolumn{8}{|c|}{ Taikymo dažnumas } & \multirow{3}{*}{$\begin{array}{c}\chi^{2} \text { tarp } \\
\text { skirtingo } \\
\text { sportavimo } \\
\text { stažo tiriaműjų } \\
\text { rodiklių }\end{array}$} & \multirow[b]{3}{*}{ p } \\
\hline & & & \multicolumn{2}{|c|}{ Niekada } & \multicolumn{2}{|c|}{ Kartais } & \multicolumn{2}{|c|}{ Dažnai } & \multicolumn{2}{|c|}{ Visada } & & \\
\hline & & & $\begin{array}{r}\text { Iki } \\
1 \mathrm{~m} .\end{array}$ & $>1 \mathrm{~m}$. & $\begin{array}{c}\text { Iki } \\
1 \text { m. }\end{array}$ & $>1 \mathrm{~m}$. & $\begin{array}{l}\text { Iki } \\
1 \mathrm{~m} .\end{array}$ & $>1 \mathrm{~m}$. & $\begin{array}{c}\text { Iki } \\
1 \mathrm{~m} .\end{array}$ & $>1 \mathrm{~m}$. & & \\
\hline \multirow[t]{2}{*}{1.} & \multirow{2}{*}{$\begin{array}{l}\text { Ritmiškas ir lètas } \\
\text { kvėpavimas }\end{array}$} & $\mathrm{v}$ & 44,4 & 12,8 & 40,7 & 64,1 & 11,1 & 20,5 & 3,7 & 2,6 & 8,71 & $<0,05$ \\
\hline & & $\mathrm{m}$ & 20,7 & 6,7 & 62,1 & 56,7 & 17,2 & 36,7 & 0 & 0 & 4,26 & $>0,05$ \\
\hline \multirow[t]{2}{*}{2.} & \multirow{2}{*}{$\begin{array}{l}\text { Specialūs kvėpavimo } \\
\text { pratimai }\end{array}$} & $\mathrm{v}$ & 66,7 & 43,6 & 29,6 & 46,2 & 0 & 10,3 & 3,7 & 0 & 6,92 & $>0,05$ \\
\hline & & $\mathrm{m}$ & 82,8 & 30,0 & 13,8 & 50,0 & 3,4 & 16,7 & 0 & 3,3 & 16,84 & $<0,05$ \\
\hline \multirow[t]{2}{*}{3.} & \multirow[t]{2}{*}{ Mankšta } & $\mathrm{v}$ & 29,6 & 2,6 & 55,6 & 51,3 & 11,1 & 30,8 & 3,7 & 15,4 & 13,39 & $<0,05$ \\
\hline & & $\mathrm{m}$ & 44,8 & 10,0 & 51,7 & 30,0 & 3,4 & 50,0 & 0 & 10,0 & 22,99 & $<0,05$ \\
\hline \multirow[t]{2}{*}{4.} & \multirow[t]{2}{*}{ Aerobiniai pratimai } & $\mathrm{v}$ & 77,8 & 46,2 & 22,2 & 38,5 & 0 & 10,3 & 0 & 5,1 & 8,18 & $<0,05$ \\
\hline & & $\mathrm{m}$ & 69,0 & 16,7 & 27,6 & 43,3 & 3,4 & 36,7 & 0 & 3,3 & 19,51 & $<0,05$ \\
\hline \multirow[t]{2}{*}{5.} & \multirow[t]{2}{*}{ Sportiniai žaidimai } & $\mathrm{v}$ & 40,7 & 17,9 & 51,9 & 46,2 & 7,4 & 33,3 & 0 & 2,6 & 8,56 & $<0,05$ \\
\hline & & $\mathrm{m}$ & 51,7 & 26,7 & 41,4 & 60,0 & 6,9 & 10,0 & 0 & 3,3 & 4,51 & $>0,05$ \\
\hline \multirow[t]{2}{*}{6.} & \multirow[t]{2}{*}{ Autogeninè treniruotè } & $\mathrm{v}$ & 88,9 & 56,4 & 7,4 & 30,8 & 3,7 & 12,8 & 0 & 0 & 7,98 & $<0,05$ \\
\hline & & $\mathrm{m}$ & 89,7 & 53,3 & 6,9 & 33,3 & 0 & 13,3 & 3,4 & 0 & 12,70 & $<0,05$ \\
\hline \multirow[t]{2}{*}{7.} & \multirow{2}{*}{$\begin{array}{l}\text { Aktyvūs tempimo } \\
\text { pratimai }\end{array}$} & $\mathrm{v}$ & 25,9 & 5,1 & 66,7 & 48,7 & 3,7 & 35,9 & 3,7 & 10,3 & 14,16 & $<0,05$ \\
\hline & & $\mathrm{m}$ & 44,8 & 10,0 & 44,8 & 53,3 & 10,3 & 26,7 & 0 & 10,0 & 11,82 & $<0,05$ \\
\hline \multirow[t]{2}{*}{8.} & \multirow[t]{2}{*}{ Pasyvūs tempimo pratimai } & $\mathrm{v}$ & 85,2 & 4,10 & 11,1 & 46,2 & 3,7 & 7,7 & 0 & 5,1 & 13,23 & $<0,05$ \\
\hline & & $\mathrm{m}$ & 89,7 & 50,0 & 10,3 & 33,3 & 0 & 16,7 & 0 & 0 & 11,71 & $<0,05$ \\
\hline \multirow[t]{2}{*}{9.} & \multirow[t]{2}{*}{ Hidroterapija } & $\mathrm{v}$ & 48,1 & 61,5 & 51,9 & 35,9 & 0 & 2,6 & 0 & 0 & 2,16 & $>0,05$ \\
\hline & & $\mathrm{m}$ & 79,3 & 33,3 & 13,8 & 53,3 & 6,9 & 10,0 & 0 & 3,3 & 13,51 & $<0,05$ \\
\hline \multirow[t]{2}{*}{10.} & \multirow[t]{2}{*}{ Meditacija } & $\mathrm{v}$ & 100 & 66,7 & 0 & 30,8 & 0 & 2,6 & 0 & 0 & 11,21 & $<0,05$ \\
\hline & & $\mathrm{m}$ & 93,1 & 63,3 & 0 & 33,3 & 3,4 & 3,3 & 3,4 & 0 & 12,38 & $<0,05$ \\
\hline
\end{tabular}

Pastaba. v - vyrai; $m$ - moterys.

su gyvūnais, kaip streso ịveikimo būdą, 17,2\% moterų taiko visada, $22,4 \%$ — dažnai, $42,4 \%$ vyru pažymejjo atsakymą ,niekada“.

Stresui íveikti rečiausiai taikoma joga (niekada jos netaiko $89,4 \%$ vyrų ir $69,5 \%$ moterų). Nustatyta, kad stresui ivveikti $70,8 \%$ vyru visai netaiko augalų auginimo, 70,3\% vyru — kvapu terapijos, $60,6 \%$ - savimasažo. $57,6 \%$ vyrų ir $33,9 \%$ moteru stresui iveikti niekada netaiko maldos.

Analizuojant rezultatus pagal respondentu sportini stažą nustatyta, kad stresui ịveikti ritmišką ir lètą kvẻpavimą dažniau taiko daugiau nei metus sportuojantys vyrai (kartais - 64,1\%, dažnai $-20,5 \%$, visada $-2,6 \%)$ nei sportuojantys iki metu (atitinkamai 40,7, 11,1 ir 3,7\%) (p < 0,05) (3 lent.), o specialius kvèpavimo pratimus dažniau taiko daugiau nei metus sportuojančios moterys (kartais - 50,0\%, dažnai - 16,7\%, visada $3,3 \%$ ) nei sportuojančios iki metu (atitinkamai $13,8,3,4$ ir $0 \%)$.

Ilgiau sportuojantys vyrai ir moterys streso įveikimui mankštą taiko dažniau, nei pradejję sportuoti: visada ją atlieka $15,4 \%$ vyru ir $10,0 \%$ moteru, sportuojančių daugiau nei metus, o iš sportuojančių iki metų visada mankštą taiko tik 
$3,7 \%$ vyru. Tiek vyrai, tiek moterys, sportuojantys daugiau kaip metus, stresui įveikti dažniau nei pradejję sportuoti taiko aerobinius pratimus, aktyvius ir pasyvius tempimo pratimus, autogeninę treniruotę, meditacija.

Sportuojantys daugiau nei metus vyrai sportinius žaidimus stresui įveikti taiko dažniau nei sportuojantys iki metų, o sportuojančios daugiau kaip metus moterys dažniau taiko hidroterapiją nei sportuojančios iki metų.

Apibendrinant galima teigti, kad sportuojančios studentės daugiau taiko atsigavimo priemoniu negu studentai vyrai. Jos dažniau $(\mathrm{p}<0,05)$ negu studentai vyrai kaip streso įveikimo būdą taiko šokius, jogą, savimasažą, kvapų terapiją, pasivaikščiojimą gamtoje, bendravimą su gyvūnais, su šeimos nariais, augalu auginimą, gèlininkystę, knygų skaitymą, meldimąsi, juoko terapiją, požiūrio i konfliktinę situaciją keitimą.

Ilgiau sportuojantys studentai (vyrai ir moterys), palyginti su pradejusiais sportuoti, kaip streso íveikimo būdą dažniau $(\mathrm{p}<0,05)$ taiko mankštą, aerobinius pratimus, autogeninę treniruotę, aktyvius ir pasyvius tempimo pratimus. Galima manyti, kad ilgiau sportuojantiems studentams stresą ivveikti labiau patinka fiziškai aktyviais būdais.

Ilgiau sportuojantys studentai (vyrai), palyginti su pradejusiais sportuoti, kaip streso iveikimo būdą dažniau taiko $(\mathrm{p}<0,05)$ ritmišką, lètą kvèpavima, sportinius žaidimus ir buvimą su draugais. Taigi vyrams bendravimas su draugais yra svarbi priemoné atsigauti po streso.

Ilgiau sportuojančios studentès, palyginti su pradejjusiomis sportuoti, kaip streso ịveikimo būdą dažniau taiko $(\mathrm{p}<0,05)$ specialius kvépavimo pratimus, psichofizinę treniruotę, hidroterapiją. Galima manyti, kad ilgiau sportuojančios studentẻs daugiau žino apie atsigavimo priemones, todèl jų streso ịveikimo būdų ịvairovè didesnè.

\section{REZULTATŲ APTARIMAS}

Kaip rodo V. Ivaškienès (Ивашкене, 2003) tyrimo duomenys, sveikatingumo ir sporto klubu lankytojai (vyrai ir moterys) fizini aktyvumą ivardija kaip streso įveikimo būdą. Atlikto tyrimo rezultatai tai patvirtina.

Lietuvos kūno kultūros akademijoje, Lietuvos žemès ūkio universitete ir Mykolo Romerio universitete atlikto tyrimo (Ivaškienè ir kt., 2007) duomenimis, neatsparūs stresui yra $6 \%$ merginu ir $8 \%$ vaikinu, vidutinio streso atsparumo yra ati- tinkamai 68 ir $64 \%$ respondentų. Gerai susidoroti su stresu geba 26 ir $28 \%$ apklaustu studentų. Taigi galima daryti prielaidą, kad mūsų tiriamieji geba geriau susidoroti su stresu, ir viena iš to priežasčiu yra fizinio aktyvumo, kaip streso įveikimo būdo, taikymas.

V. Ivaškienès ir kt. (2007) tyrimo duomenimis, studentès merginos kaip streso ịveikimo būdus dažniau nei vaikinai taiko socialinès paramos prièmimą (t. y. draugų pagalbą ir dalijimąsi jausmais bei rūpesčiais su artimais žmonėmis). Mūsų tirtos studentès taip pat dažniau nei studentai vyrai kaip pagalbą i̇veikdamos stresą taiko bendravimą su šeimos nariais.

Taigi apibendrinant galima teigti, kad ilgesni laiką nuolat besimankštinančiu studentų streso ivveikimo būdų taikymas yra dažnesnis ir įvairesnis nei tik pradejusiuju sportuoti. Galima pastebèti, kad sportuojantys studentai suvokia fizini aktyvumą kaip streso įveikimo būdą, jị dažnai taiko, tik pasirenka maloniausias, labiausiai patinkančias fizinio aktyvumo formas, o tai kaip tik ir rekomenduoja dauguma literatūros šaltinių (Martinsen et al., 1989; Weigand, 1998; O'Hanlow, 1999; Henry, 2005; Ivaškienè, Čepelionienè, 2005; Masiulis, 2006).

Tyrimo rezultatų analizė atskleidè, kad respondentai dar nèra susipažinę su ịvairiais streso Ł̇veikimo būdais. Pavyzdžiui, mažai taikoma meditacija, psichofizinè, autogeninè treniruotè. R. Rothas (Ротx, 1994) nurodo, kad mažai žmoniu yra susipažinę su meditacija, nežino jos įtakos stresui iveikti, todèl nedaugelis ją ir renkasi. K. Dineika (2001) teigia, kad apie psichofizinę treniruotę žino tik sportuojantys žmonès, nes ji dažnai taikoma rengiantis varžyboms ir atsigaunant po jų. Apie autogeninès treniruotès naudą íveikiant stresa taip pat sužinoma tik iš ją propaguojančiu sporto trenerių (Hertzer, 2003). Galima manyti, kad žmonėms nepakanka informacijos apie streso įveikimo būdus — tai būtu galima patikrinti tolesniais tyrimais.

Mūsų iškelta hipotezè, kad didesni sportinį stažą turintys sportuojantys studentai taiko daugiau streso įveikimo būdų, o moterys - daugiau nei vyrai, pasitvirtino.

Būtų tikslinga atlikti išsamesnị tyrimą ir nustatyti, ne tik kokios pagalbos, informacijos apie streso įveikimo būdus sportuojantiems studentams trūksta, bet ir ko jie tikisi iš sveikatingumo bei sporto klubų darbuotojų. 


\section{IŠVADOS}

1. Sportuojantys studentai (vyrai ir moterys) stresui ịveikti dažniausiai taiko bendravimą su šeimos nariais ir juoką. Sportuojančios studentès dažniau negu studentai $(\mathrm{p}<0,05)$ stresui įveikti taiko šokius, jogą, savimasažą, kvapų terapija, pasivaikščiojimą gamtoje, bendravimą su šeimos nariais, su gyvūnais, augalų auginimą, knygų skaitymą, meldimąsi, juoko terapiją, požiūrio ị konfliktinę situaciją keitimą.
2. Ilgiau kaip metus sportuojantys studentai, palyginti su sportuojančiais iki metų, kaip streso iveikimo būdą dažniau $(\mathrm{p}<0,05)$ taiko mankštą, aerobinius pratimus, aktyvius ir pasyvius tempimo pratimus, autogeninę treniruotę, meditaciją. Ilgiau sportuojantys vyrai dažniau taiko ritmišką ir lètą kvėpavimą, ilgiau sportuojančios moterys - specialius kvėpavimo pratimus.

\section{LITERATŪRA}

Carr, A. (2004). Positive pshychology. The Sience of Happiness and Human Strenghts. New York: Hove.

Dineika, K. (2001). Psichofizine treniruote. Vilnius: LSIC.

Forge, R. L. (1993). A closer look at endorphins and exercise. Bind. Body fitness. Published by IDEA.

Grakauskas, Ž., Valickas, G. (2006). Streso įveikos klausimynas: keturių faktorių modelio taikymas. Psichologija, $33,64-75$.

Gray, P. (2001). The music of nature and the nature of music. Science, 291, 52-56.

Henry, J. (2005). Asmeninis energijos šaltinis. Vilnius: Algarvè.

Hertzer, K. (2003). Autogeninè treniruotè. Vilnius: Mūsu knyga.

Ivaškienè, V. (2003). Atsipalaidavimo pratimai. V. Volbekienè (Sud.), Eurofitas: fizinio pajègumo testai ir metodika. Lietuvos studentu fizinio pajegumo rezultatai. Vilnius: LSIC. P. 139.

Ivaškienè, V., Čepelionienė, J. (2005). Studentu fizinis ugdymas ir saviugda. Kaunas: LKKA. P. 152-185.

Ivaškienè, V., Liaudanskas, S., Kšanauskienè, L., Čepelionienè, J. (2007). Studentų streso ịveikimo būdai. Kultūra -Ugdymas - Visuomene: mokslo darbai, 2, $255-258$.

Lindop, E. (1999). A comparative study of stress between pre- and post- Project 2000 students. Journal of Advanced Nursing, 29 (4), 967-973.

Martinsen, E. W., Hoffart, A., Solberg, O. (1989). Aerobic and non-aerobic forms of exercise in the treatment of anxiety disorders. Stress Medicine, 5, 115-120.
Martinsen, E. W. (1994). Physical exercise and depression. Clinical experience. Acta Psychiatrica Scandinavia, 3 (77), 23-27.

Masiulis, N. (2006). Fizinio aktyvumo poveikis stresui, nerimui ir depresijai mažinti. Šiuolaikinių technologijų analizè. Fizinis aktyvumas ir sveikata (pp. 99-116). Kaunas: LKKA.

O’Hanlon, B. (1999). Stresas. Kaunas: Gaivata.

Palujanskienè, A., Pikūnas, J. (2005). Stresas. Atpažinimas ir iveikimas. Kaunas: Pasaulio Lietuvių Centras.

Paluska, S. A., Schwenk, T. L. (2000). Physical activity and mental health. Sports Medicine, 29 (3), 167-180.

Raglin, J. (1995). Exercise and mental health. In IDEA Tody 7. International Association of Fitness Profesionals, $60,15-21$.

Ratcliffe, G. (2006). Jei stresas trukdo gyventi. Laimingo ir sveiko gyvenimo planas. Raudondvaris: Dajalita.

Selye, H. (1976). The Stress of Life. New York: McGrawHill.

Treben, M. (2006). Kasdienis stresas. Vilnius: Algarvè. Weigand, V. (1998). Moteru stresai. Vilnius: Alma Litera.

Ивашкене, В. (2003). Релаксация и качество жизни. VII международный научный конгресс «Современный олимпийский спорт и спорт для всех»: материаль конференций. Т. 1. Москва: Российский гос. университет физической культуры, спорта и туризма. С. 134-135. Полтавцев, И. Н. (1991). Йога делового человека. Минск: Полымя.

Ротх, Р. (1994). Трансиедентальная медитаичия. СанктПетербург: Ао Санкт-Петербургская типография № 6. 


\title{
STRESS MANAGEMENT TECHNIQUES USED BY PHYSICALLY ACTIVE STUDENTS
}

\author{
Vida Ivaškiené ${ }^{1}$, Liudmila Kšanauskiené ${ }^{1}$, Jurgita Čepelionienè $\dot{e}^{1,2}$, \\ Jolanta Bogužiené ${ }^{3}$, Dainius Daukšas ${ }^{4}$ \\ Lithuanian Academy of Physical Education, Kaunas ${ }^{1}$, Mykolas Romeris University, Vilnius ${ }^{2}$, \\ PO Alzheimer Nursing Home „, Amžiaus žiedas “, Kaunas ${ }^{3}$, Kaunas Sport Club „,Dainralfas “, Kaunas", \\ Lithuania
}

\begin{abstract}
The aim of the research was to determine stress management techniques used by physically active students (males and females).

The research methods used in this work were literature review, written questionnaire, percentage analysis and mathematical statistics.

The questionnaire contained 34 stress-management techniques and the respondents had to mark one of the four possible answers: A - never, B - sometimes, C - often, and D - always.

The survey with this anonymous questionnaire was carried out after training sessions in fitness and sports clubs located in Kaunas city in November, 2007. The respondents were 125 students (66 males and 59 females) aged from 18 to 25 years (Arithmetical mean was $22.6 \pm 2.5$ years) who exercised $2-3$ times per week. According to their years of experience in sports the respondents were divided into two groups: those who had exercised less than 1 year and those who had exercised more than 1 year. The time given to fill in the questionnaire was $10-12$ minutes.

Statistical analysis of the research data was done by using SPSS 13.0 package. To establish the reliability of the results in different groups $\chi^{2}$ (chi squared criterion) was used.

The survey showed that physically active students (male and female) most often used communication with family members and laughter for their stress management. The research results also showed that female members of fitness and sports clubs more often than male members $(p<0.05)$ used such stress relieving techniques as dance, yoga, massage therapy, aromatherapy, walking in the park, petting animals, communication with their family members, gardening, reading books, prayer, laughter, change of their attitude to a stressful situation after stressful activities.

Students who exercised more than one year more often $(p<0.05)$ prefered exercises, aerobic exercise, training, active and passive stretching, autogenous training and meditation for stress management. Male students who exercised for a longer period of time more often used rhythmic and slow breathing, while female students used special breathing exercises.
\end{abstract}

Keywords: sport, stress, stress management techniques.

Gauta 2008 m. gegužès $1 \mathrm{~d}$.

Received on May 1, 2008

Vida Ivaškiené

Lietuvos kūno kultūros akademija

(Lithuanian Academy of Physical Education)

Sporto g. 6, LT-44221 Kaunas

Lietuva (Lithuania)

Tel +37037302645

E-mail v.ivaskiene@lkka.1t 